\title{
Predispersal infestation of Vochysia haenkeana seeds by Lius conicus
}

\section{Samara Letícia Oliveira Lourenço ${ }^{1}$ Marcelo Felix Luiz ${ }^{1}$ Flávio Gonçalves de Jesus ${ }^{2}$ Daniel Diego Costa Carvalho ${ }^{1}$ Michael Hornburg ${ }^{3}$ Márcio da Silva Araújo ${ }^{1^{*}}$}

${ }_{1}^{1}$ Universidade Estadual de Goiás (UEG), GO 330, Km 241, Anel Viário, s/n, 75780-000, Ipameri, GO, Brasil. E-mail: marcio.araujo@ueg.br. ${ }^{*}$ Corresponding author.

${ }^{2}$ Instituto Federal Goiano (IF Goiano), Campus Urutaí, Urutaí, GO, Brasil.

${ }^{3}$ Kavalierstraße 11, D-13187, Berlin, Germany.

\begin{abstract}
The deficient development of fertile seeds of native forest plant species in Brazil limits the reproduction of these plants in various conditions. Among the limiting biotic factors in quality and quantity of the forest seeds, borer insects are quite prominent, before and after their dispersion. This study reports for the first time a host of the buprestid beetle Lius conicus (Gory \& Laporte, 1840). The larval development of L. conicus takes place in the seed capsules of Vochysia haenkeana Mart. (Vochysiaceae), a typical tree species in the Brazilian cerrado biome. In two regions of the cerrado in Goiás State, Brazil, almost ripe fruits of $V$. haenkeana were collected directly from the plants. After natural drying, and fruit and seed processing in laboratory, damage caused by the L. conicus larvae was quantified and qualified. Bigger fruits were preferred as hosts. Fruits developing on the eastern side of the plant were most frequently occupied by L. conicus. Seed lots of bigger fruits showed damage up to $37.5 \%$ from the infestation by L. conicus larvae. There was only one larva per fruit, which damaged all the seeds of the capsule (three or four) and generally consumed around $26 \%$ of the seed dry mass.
\end{abstract}

Key words: Brazilian cerrado, "pau-amarelo", seed damage, insect.

Infestação pré-dispersão de sementes de Vochysia haenkeana por Lius conicus

RESUMO: O deficiente desenvolvimento de sementes férteis de espécies florestais nativas no Brasil limita a propagação dessas plantas em diversas condições. Entre os fatores bióticos limitantes da qualidade e quantidade das sementes florestais, destacam-se os insetos broqueadores, antes e depois da sua dispersão. Este estudo relata pela primeira vez um hospedeiro do besouro buprestideo Lius conicus (Gory \& Laporte, 1840). O desenvolvimento larval de L. conicus ocorre em cápsulas com sementes de Vochysia haenkeana Mart. (Vochysiaceae), uma típica árvore do bioma cerrado brasileiro. Em duas regiões do cerrado, no Estado de Goiás, no Brasil, frutos quase maduros de V. haenkeana foram coletados diretamente das plantas. Após secagem natural e beneficiamento de frutos e sementes em laboratório, os danos causados pelas larvas de L. conicus foram quantificados e qualificados. Frutos maiores foram os preferidas como hospedeiros desse inseto. Os frutos produzidos pela planta, voltados para ponto o cardeal leste, foram os mais infestados por L. conicus. Lotes de sementes provenientes de frutos maiores apresentaram infestação por L. conicus de até 37,5\%. Observou-se que houve apenas uma larva desse inseto por fruto, que danificou todas as sementes da cápsula (três ou quatro) e consumiu geralmente cerca de $26 \%$ da massa seca da semente.

Palavras-chave: Cerrado brasileiro, pau-amarelo, dano em semente, inseto.

\section{INTRODUCTION}

The semideciduous tree Vochysia haenkeana (Vochysiaceae), commonly known in the Brazilian Cerrado as "pau-amarelo", "escorrega-macaco" or "cambarazinho" can reach a height between 8 to $20 \mathrm{~m}$, with a diameter of the trunk up to 60cm (NETO, 1991; RIZZI et al., 2016). Wood from $V$. haenkeana is used for firewood, civil construction, furniture manufacturing, coffers, toys and various tool handles (VIANNA, 1980; LORENZI, 2013). LORENZI (2013) mentioned possible use of this species in silvipastoral systems, as well as an ornamental plant due to the color of its trunk and the exuberance of its yellow flowering. In addition, PASA (2011) mentioned that the bark of this tree is also used as tea for respiratory diseases. 
Similar to other tree species from the cerrado, $V$. haenkeana is tolerated as a single plant or in small groups, to provide shade to the cattle, or where it is not disturbing agriculture and large monocultures. The last remaining refuges for this tree species are limited to small permanent preservation areas, close to water streams.

Seed dispersal is one of the key phases in the regeneration process of plant populations (TRAVESET et al., 2014) and, as a component of this process, the seed predators can impose a strong selection pressure on plants (JANZEN, 1980; MARON \& GARDNER, 2000). There are two basic types of seed predation: predispersal predation, which occurs while the seed is still attached to the mother plant; and post-dispersal predation, which occurs after separation from the mother plant but before the germination process begins (JANZEN, 1971). Intensity of predispersal and post-dispersal infestation by several predators contributes significantly to seed mortality, affecting the distribution of several forest species (ZHANG et al., 1997; SANTOS et al., 2001). Some studies show that the fruits and/or seeds of a great number of economically or ecologically valuable native tree species are regularly damaged by different groups of insects (HULME \& BORELLI, 1999; SANTOS et al., 2001; SARI et al., 2002; MEIADO et al., 2013), many of which are strikingly preyspecific (JANZEN, 1980). Predispersal predation by insects may cause mortality in up to $80 \%$ of the seeds produced in many grassland and forest habitats (ANDERSEN, 1988).

Insect damage to seeds and embryos usually prevents them from developing and germinating (BRADFORD \& SMITH, 1977; ZHANG et al., 1997; RIBEIRO et al., 2007). According to SANTOS et al. (1997) and LOUREIRO et al. (2004), the most frequent seed damaging insects of native forest species, especially Fabaceae, are Coleoptera belonging to Bruchidae, Anthribidae, Curculionidae and Cerambycidae, Diptera of the Tephritidae family and Lepidoptera of Pyralidae family. In addition to these, SARI et al. (2002) mentioned Tenebrionidae and Hymenoptera species as possible causing agents of damages in seeds of native Brazilian trees.

Buprestidae is the seventh most diverse family of the order Coleoptera, possessing around
15,000 species (BELLAMY \& NELSON, 2002). In contrast with the previous groups, most buprestid species are wood-borers or leafminers (LIMA, 1953; HESPENHEIDE, 1991; CORONA \& TOLEDO, 2006; HESPENHEIDE \& CHABOO, 2015), with rare records as seed predators.

The aim of this study is to identify insects associated with $V$. haenkeana seeds, in the predispersion phase, as well as quantify and qualify the damages caused in the fruits and seeds by insects.

\section{MATERIALS AND METHODS}

Adult trees of $V$. haenkeana were randomly selected in two different regions of the cerrado in the Municipalities of Caldas Novas, GO, Brazil (lat. $17^{\circ} 43^{\prime} 34$ 'S; long. 48 34' 10”W; alt. $625 \mathrm{~m}$ ) and Pires do Rio, GO, Brazil (lat. $17^{\circ}$ 03' 61'S; long. 48 49' 46”W; alt. 755m). Both areas are small fragments of riparian forests of permanent preservation. The distance between these areas is $61 \mathrm{~km}$. In each one, 15 trees with diameter at breast height (DBH) bigger than $30 \mathrm{~cm}$ and height between 8 and $15 \mathrm{~m}$ were selected. Randomly, throughout the medium and lower canopy of the tree, 15 small branches containing about 35 still green fruits were collected. Fruits were collected from these trees at two different periods. The first removal took place in 2014 in Caldas Novas and the other in 2015 in Pires do Rio. Minimum distance between the harvested trees in each area was at least $100 \mathrm{~m}$, in order to guarantee the independence of the samples.

In Caldas Novas, fruits were collected once, when most of fruits presented a green color and some were already ripe before dispersing seeds. After removal from the branches, all fruits were grouped in a single sample. Fruits were dried in the natural environment in 10 ventilated (six holes, with a $2.0 \mathrm{~cm}$ diameter) plastic containers with a 3.0L capacity. Holes in the lids were covered with a micro-perforated fabric ("tulle" type), to prevent the emerging insects from escaping. Subsequently a quantification and identification of all insects, emerging from the capsules, was conducted, as well as germination tests with the remaining seeds.

In Pires do Rio, at the selected 15 trees, unripe fruits were collected in three different states. 
The first harvest was made when trees still showed abundant flowering and young fruits. The second and third harvest took place 15 and 30 days later, respectively. Procedure for collecting, drying and processing of fruits and seeds was the same as in Caldas Novas. Number of damaged fruits and seeds was quantified and capsule size (length) was measured to look for correlations between fruit size and damage. Length of fruits was measured with a digital caliper in the laboratory. Another question was if the exposure of the fruits to the sun (east or west position) would influence the quantity of damage by the insect. For this purpose, the tree was divided in half and, randomly, fruits were collected from both eastern and the western extremity side. The orientation for the collection points of fruits in the tree canopy was made with the use of a compass.

After natural drying in the laboratory, when there was no observance of emergence of adult insects in the stored seeds or capsules, the seeds were quantified and qualified. Four seed lots with 50 damaged seeds by the insect, and same amount of undamaged seeds, were weighed. For this, the seeds were placed in a forced draft oven $\left(105 \pm 3^{\circ} \mathrm{C}\right)$ for 24 hours, following the recommendation by the Rules for Seed Analysis (BRASIL, 2009).

All seeds collected in Caldas Novas $(n=3120)$ were classified in the following categories: undamaged, damaged seeds (by insects) and empty or deformed husks. The percentage of seeds consumed by the bupretid larvae was estimated by the difference of dry matter of undamaged and damaged by insect. For this, out of the total number of damaged and undamaged seeds $(n=50)$ were randomly removed and weighed.

Germination of damaged seeds by $L$. conicus and intact seeds were compared. For this purpose, seeds were spread on germitex paper and transferred directly to germination chambers, according to the methodology in BRASIL (2009). In this treatment (germitex paper roll containing 25 seeds damaged or undamaged by the insect), with four replicates for each treatment, the seeds were allowed to germinate for 30 days. The seed was considered germinated when radicles were visible in this period.

A chi-square test $\left(\chi^{2}\right)$ was conducted to test the location of fruit in the tree (east or west orientation) and the intensity of the damage caused by insects. Comparison between the fruit and the presence of L. conicus in it was performed using Spearman's correlation coefficient. These analyses were processed with the SISVAR 5.3 Software (FERREIRA, 2011).

\section{RESULTS AND DISCUSSION}

Regardless of the location of the fruit collection and the year of the collection, only one borer insect species in the seed of $V$. haenkeana was present. In our study, the number of emerged adult insects from the seeds was not quantified. However, confirmation of the single borer species was done with the collection of more than one hundred adult insects in the two distinct studied localities. In addition to these insects, the presence of Hymenoptera, possibly parasitoid of the young forms of the insect borer, was verified inside the plastic containers protected with "tulle". The borer insect, identified as Lius conicus (Gory \& Laporte, 1840) (=syn. Lius nobilis Obenberger, 1924) belonging to the family Buprestidae, is around $5.7 \mathrm{~mm}$ in length (Figure 1). The buprestid species was identified by the fifth author of this research. The "voucher specimen" was deposited in the entomological collection of the Universidade Estaudal de Goiás, Ipameri, Goiás, Brazil.

Records of insects and their host plants are scarce for the vast majority of phytophagous insect species in Brazil, and are mainly composed of species of agricultural interest or vectors of disease (FLINT et al., 2006; SILVEIRA et al., 2008). In these records, Buprestidae preying on seeds is a rare event. Few records of Lius in the literature mention some species which only feed on the leaves (NAKAHARA et al., 1992; FLINT et al., 2006). However, coincidentally, CUSTÓDIO et al. (2014) reported the incidence of buprestid larvae (unidentified, but possibly the genus Lius) preying on Qualea seeds, which is also from the same plant family as the one in our study. Thus, future researches should be developed to understand the relationship between $L$. conicus and other species of Vochysiaceae in the region of our study.

The damage on the unripe fruit, caused by the insect larva, is very typical, an exudate (gum), shown in figure 1 . Only one perforation with exudate 


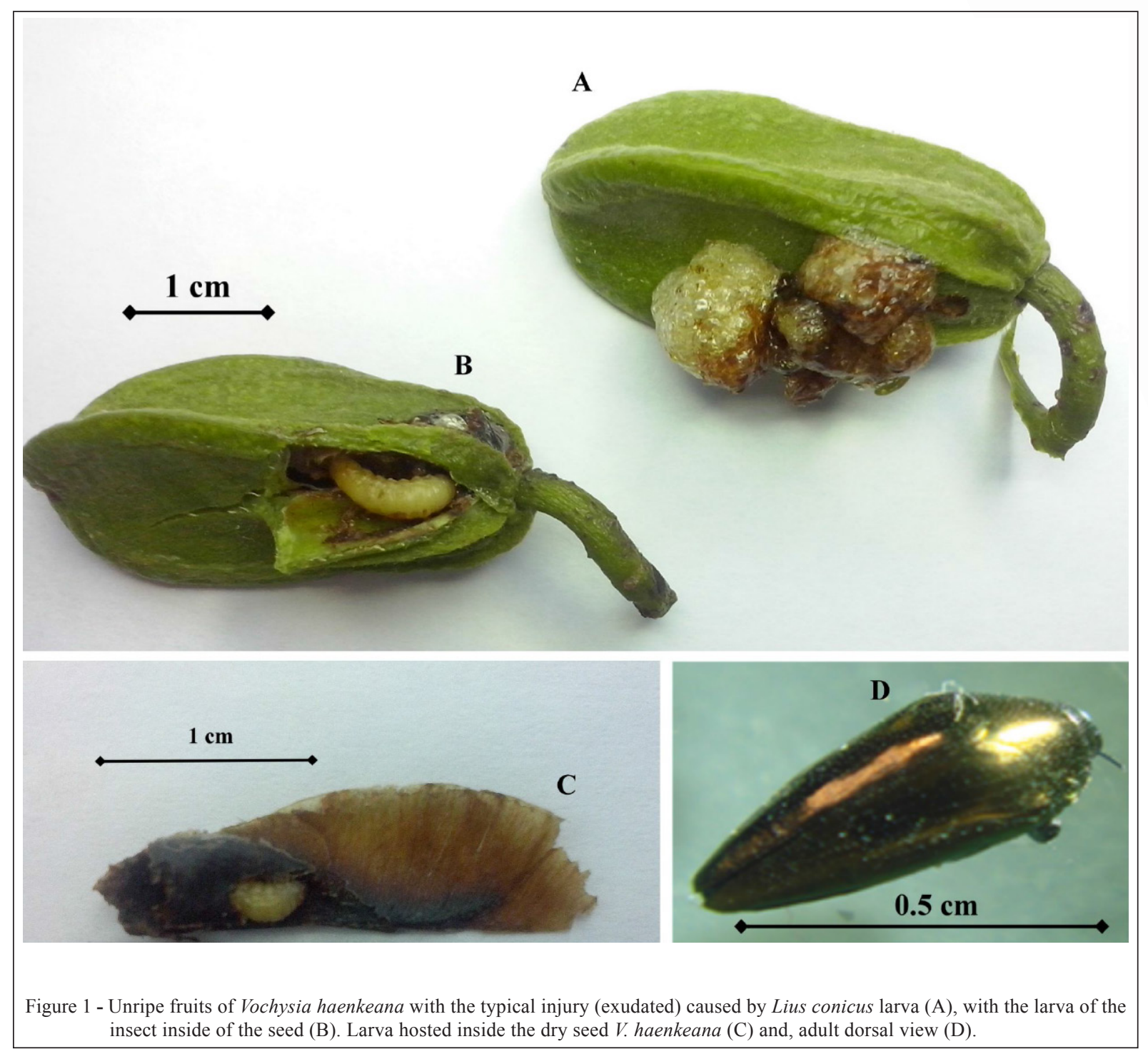

per fruit was observed. All unripe fruit with typical signs of infestation by L. conicus lost all the seeds (three or four) to the buprestid larvae. Due to the fruit architecture, seeds are very close to each other and easily reachable by the larva.

The fact that no specific exit holes of the adults of $L$. conicus were observed indicates that the adult left the dehiscent fruit capsule at the time of the dispersion of the seed, similar to Apion spp. (Coleoptera: Brentidae) in seeds of Copaifera (Fabaceae) (SANTOS et al., 2015). During the natural dried seed processing, several adult insects were removed from the capsules, which supports this hypothesis.

Of the 900 sampled fruits in Caldas Novas, after seed processing in laboratory, $62.5 \%$ contained undamaged seeds; $19.75 \%$ contained seeds destroyed by L. conicus, and $17.75 \%$ did not show any attack, but presented empty husks. The lower quantity of $V$. haenkeana seeds occupied by L. conicus when compared with intact seeds, can be a natural defense system of this plant. This strategy of defending plants in general from insects was mentioned by JANZEN (1971). 
Considering the weight of five lots with 50 seeds undamaged and damaged by L. conicus larvae: $(0.4526 \pm 0.1572 \mathrm{~g}$ - undamaged seeds and $0.3355 \pm 0.0298 \mathrm{~g}$ - damaged seeds), it was estimated that around $26 \%$ of seed dry matter was consumed by the insect larvae. Endosperm and embryos of seeds were preferred and almost completely consumed, whereas the wing and outer part of the seed coat were found remaining (Figure 1, L. conicus larva in dry seed of $V$. haenkeana).

Of the sampled fruits in Pires do Rio, (after flowering and appearance of the first fruits $(n=1691)$, the second $(n=1374)$, the third $(n=1821)$ collections, 15 and 30 days after the first one) the attacks of L. conicus were recorded in $3.02 \%$, $7.13 \%$ and $37.50 \%$ for each collection of fruits, respectively. A significant correlation between fruit length and its infestation by L. conicus (Spearman, $\mathrm{c}=0.955 ; \mathrm{P}<0.05)$ was observed. Since during the second collection of fruits a large quantity of small and unripe fruits was observed, one can infer that the adult of this pest prefers oviposition in bigger fruits (Table 1). Female L. conicus prefers oviposition in fruits located towards the east part of the plant $\left(\chi^{2}=245.22 ;\right.$ d.f. $\left.=44 ; \mathrm{P}<0.05\right)$ (Table 2$)$. Maybe fruits and seeds in this orientation provide better quality, conditions or microclimate for the survival of the insect larva. This information could be useful for fruit and seed collections for the seedling production programs. For example, SANTOS et al. (2001) observed seed infestation of Anandenanthera peregrina L. Speg. (Fabaceae) by insects when found towards east and north of the tree. These authors suggest avoiding the collection
Table 1 - The length of Vockysia haenkeana fruits and perforated fruits by Lius conicus. Pires do Rio, Goiás, Brasil, 2015.

\begin{tabular}{lc}
\hline Length class $(\mathrm{cm})$ & Bored fruits \\
\hline$<0.5$ & 0 \\
$0.51-1.0$ & 0 \\
$1.01-1.5$ & 10 \\
$1.51-2.0$ & 42 \\
$2.01-3.0$ & 216 \\
$3.01-3.5$ & 297 \\
$>3.51$ & 265 \\
\hline
\end{tabular}

Significant correlation between fruit length and attacks by $L$. conicus (Spearman's correlation: $\mathrm{r}=0.955 ; \mathrm{P}<0.05 ; \mathrm{n}=45$ plants).

of seeds in those areas of the plant for seedling production programs.

Undamaged seeds from Caldas Novas $(67 \pm 5.1 \%)$ and from Pires do Rio (85 $\pm 1.5 \%)$ germinated. None of the damaged seeds germinated. The last instar of the larva of $L$. conicus has the same length of the seed, as shown in figure 1, and it consumes nearly the whole internal content of the fruit capsule, including the seeds, or part of the seeds.

\section{CONCLUSION}

In this research, a host plant ( $V$. haenkeana) of buprestid L. conicus is recorded for the first time. In the study area, only this insect borer was reported in the seeds. This event occurred before seed dispersal and significantly compromised seed production.

Table 2 - Injuries caused to Vockysia haenkeana fruits by Lius conicus in relation to the location in the plant. Pires do Rio, GO, Brasil, 2015.

\begin{tabular}{|c|c|c|c|}
\hline \multirow[t]{2}{*}{ Collection $^{*}$} & ----------------P & lants----------------------------------- & \multirow[t]{2}{*}{ Undamaged fruits } \\
\hline & East position & West position & \\
\hline $1^{\text {st }}$ & 36 & 15 & 1640 \\
\hline $2^{\text {nd }}$ & 42 & 54 & 1278 \\
\hline $3^{\text {rd }}$ & 433 & 250 & 1138 \\
\hline
\end{tabular}

*Different occasions of fruit collection: the first, right after flowering and appearance of the first fruits, the second and third collections, 15 and 30 days after the first collection, respectively. 


\section{ACKNOWLEDGEMENTS}

To Universidade Estadual de Goiás for facilitating this research through research grants (programs BIC and BIP). To Free Access Consultoria de Idiomas for reviewing the English version of the manuscript. We are also grateful to the editor and two anonymous reviewers for improvement of this manuscript and their invaluable suggestions.

\section{REFERENCES}

ANDERSEN, A.N. Insect seed predators may cause far greater losses than they appear to. Oikos, v.52, p.337-340, 1988. Available from: <http://www.jstor.org/stable/3565207?origin=JSTORpdf\&seq=1\#page_scan_tab_contents $>$. Accessed: Feb. 03, 2017. doi: $10.2307 / 3565207$.

BELLAMY, C.L.; NELSON, G.H. Buprestidae Leach, 1815. In: ARNETT, R.H.J. et al. American beetles. 2. Polyphaga: Scarabaeoidea through Curculionoidea. Boca Raton, FL: CRC, 2002. V.1, p.98-112. Available from: <http://coleopsoc.org/ buprestidae/PDF/Bellamy/Bellamy\&Nelson2002.pdf $>$. Accessed: Feb. 21, 2017.

BRADFORD, D.F.; SMITH, C.C. Seed predation and seed number in Scheelea palm fruits. Ecology, v.58, n.3, p.667-673, 1977. Available from: <http://www.jstor.org/ stable/1939017?seq=1\#page_scan_tab_contents $>$. Accessed: Feb. 04, 2017. doi: 10.2307/1939017.

BRASIL. Regras para análise de sementes. Brasília: Ministério da Agricultura e Reforma Agrária. Secretaria Nacional de Defesa Agropecuária, 2009. 365p.

CORONA, A.M.; TOLEDO, V.H. Patrones de distribución de la familia Bupretidae (Coleoptera). In: MARRONI, J.J.; BOUSQUETS, J.L. Componentes bióticos principales de la fauna mexicana. México, D.C.: UMAN, 2006. p.333-391. Available from: <http://coleopsoc.org/buprestidae/PDF/Corona/ Corona\%20\&\%20Toledo\%202006.pdf>. Accessed: Feb. 01, 2017.

CUSTÓDIO, L.N. et al. Pre-dispersal seed predation and abortion in species of Callisthene and Qualea (Vochysiaceae) in a Neotropical Savanna. Acta Botanica Brasilica, v.28, n.3. P.309320, 2014. Available from: <http://www.scielo.br/pdf/abb/v28n3/ a02v28n3.pdf $>$. Accessed: Feb. 02, 2017. doi: 10.1590/0102$33062014 \mathrm{abb} 3064$.

FERREIRA, D.F. Sisvar: a computer statistical analysis system. Ciência e Agrotecnologia, v.35, n.6, p.1039-1042, 2011. Available from: <http://www.scielo.br/pdf/cagro/v35n6/a01v35n6>. Accessed: July 26, 2016.

FLINT, V. et al. Insetos fitófagos associados ao murici da praia Byrsonima sericea (Malpighiaceae), na Restinga de Jurubatimba (RJ). Revista Brasileira de Entomologia, v.50, n.4, p.512523, 2006. Avaliable from: <http://www.scielo.br/pdf/rbent/ v50n4/12.pdf>. Accessed: Feb. 02, 2017. doi: 10.1590/S008556262006000400012 .

HESPENHEIDE, H.A. Bionomics of leaf-mining insects. Annual Review Entomology, v.36, p.535-560, 1991. Available from: <http://www.annualreviews.org/doi/pdf/10.1146/annurev. en.36.010191.002535>. Accessed: Feb. 04, 2017. doi: 10.1146/ annurev.en.36.010191.002535.
HESPENHEIDE, H.; CHABOO, C.S. Beetles (Coleoptera) of Peru: a survey of the families - Buprestidae. Journal of the Kansas Entomological Society, v.88, n.2, p.211-214, 2015. Available from: $<$ http://www.bioone.org/doi/full/10.2317/kent-88-02-211-214.1>. Accessed: Feb. 16, 2017. doi: 10.2317/kent-88-02-211-214.1.

HULME, P.E.; BORELLI, T. Variability in post-dispersal seed predation in deciduous woodland: relative importance of location, seed species, burial and density. Plant Ecology, v.145, p.149-156, 1999. Available from: <http://link.springer.com/article/10.1023 /A:1009821919855>. Accessed: July 26, 2016.

JANZEN, D.H. Seed predation by animals. Annual Review of Ecology and Systematics, v.2, p.465-492, 1971. Available from: <http://www.annualreviews.org/doi/pdf/10.1146/annurev. es.02.110171.002341>. Accessed: July 20, 2016. doi: 10.1146/ annurev.es.02.110171.002341.

JANZEN, D.H. Specificity of seed-attacking beetles in a Costa Rican Deciduous Forest. Journal of Ecology, v.68, n.3, p.929-952, 1980. Available from: <http://www.jstor.org/ stable/2259466? origin $=$ JSTOR-pdf\&seq $=1 \#$ page scan tab contents $>$. Accessed: Feb. 02, 2017. doi: 102309/2259466.

LIMA, C. Insetos do Brasil: Coleópteros 2a Parte. Rio de Janeiro: Escola Nacional de Agronomia, UFRRJ, 1953. 325p. (Série Didática, n.10). Available from: <http://www.ufrrj.br/institutos/ib/ ento/tomo08.pdf>. Accessed: Feb. 01, 2017.

LORENZI, H. Árvores brasileiras: manual de identificação e cultivo de plantas arbóreas do Brasil. 4.ed. Nova Odessa: Instituto Plantarum, 2013. V.2, 384p.

LOUREIRO, M.B. et al. Danos causados por insetos na germinação e no vigor de sementes de Apuleia leiocarpa vog. Macbride. Agronomia, v.38, n.1, p.105-109, 2004. Available from: <http:// www.ia.ufrrj.br/revista/vol.\%2038\%20-\%202004/R.Agron. $\% 20$ 01/Trab.\%20018\%20-\%20Danos\%20causados\%20por.pdf>. Accessed: July 23, 2016.

MARON, J.L.; GARDNER, S.N. Consumer pressure, seed versus safe-site limitation, and plant population dynamics. Oecologia, v.124, p.260-269, 2000. Available from: <http://hs.umt.edu/ $\mathrm{dbs} /$ labs/maron/documents/publications/maron $\% 20$ and $\% 20$ gardner\%202000.pdf>. Accessed: May 05, 2017.

MEIADO, M.V. et al. Entomofauna associated to fruits and seeds of two species of Enterolobium Mart. (Leguminosae): Harm or benefit? Revista Brasileira de Entomologia, v.57, n.1, p.100104, 2013. Available from: <http://www.scielo.br/pdf/rbent/v57n1/ a15v57n1.pdf $>$. Accessed: July 07, 2016. doi: 10.1590/S008556262013000100015.

NAKAHARA, L.M. et al. Review and status of biological control of Clidemia in Hawaii. In: STONE, C.P. et al. Alien plant invasions in native ecosystems of Hawaii: management and research. Hawaii, USA: University of Hawaii, Cooperative National Park Resources Studies Unit, Honolulu, 1992. p.452-465.

NETO, G.G. Plantas do Brasil: angiospermas do estado de Mato Grosso-Pantanal. Acta Botânica Brasil, v.99, n.1, p.25-47, 1991. Available from: <http://www.scielo.br/pdf/abb/v5n1/v5n1a03>. Accessed: July 22, 2016.

PASA, M.C. Saber local e medicina popular: a etnobotânica em Cuiabá, Mato Grosso, Brasil. Boletim do Museu Paraense Emílio 
Goeldi, v.6, n.1, p.179-196, 2011. Available from: <http://www. scielo.br/pdf/bgoeldi/v6n1/a11v6n1.pdf>. Accessed: July 26, 2016.

RIBEIRO, M.L. et al. Influência da predação de sementes na germinação de leguminosas (Fabaceae) no Cerrado. Revista Brasileira de Biociências, v.5, n.2, p.279-281, 2007. Available from: <http://www.ufrgs.br/seerbio/ojs/index.php/rbb/article/ download/248/236>. Accessed: May 05, 2017.

RIZZI, E.C. et al. Allelopathic potential and phytochemistry of cambarazinho (Vochysia haenkeana (Spreng.) Mart.) leaves in the germination and development of lettuce and tomato potencial alelopático e fitoquímica das folhas de cambarazinho na germinação e desenvolvimento de alface e tomate. Bioscience Journal, v.32, n.1, p.98-107, 2016. Available from: <http://www.seer. ufu.br/index.php/biosciencejournal/article/view/29614/17756>. Accessed: July 15, 2016. doi: 29614/17756.

SANTOS, G.P. et al. Danos causados por Rhyssomatus sp. (Coleoptera; Curculionidae), Triaspis sp. (Hymenoptera; Braconidae) e Lepidoptera (Pyralidae) em sementes de angico vermelho Piptadenia peregrina (Leguminosae). Revista Ceres, v.48, n.279, p.539-549, 2001. Available from: <http://www.ceres. ufv.br/ojs/index.php/ceres/article/viewFile/2744/838>. Accessed: July 26, 2016.

SANTOS, G.P. et al. Daños por Sennius amazonicus, Sennius sp. y Amblycerus sp. (Coleoptera: Bruchidae) en semillas de Sclerobium sp. (Leguminosae). Revista de Biología Tropical, v.45, p.883886, 1997. Available from: <http://revistas.ucr.ac.cr/index.php/rbt/ article/view/20926/21081>. Accessed: July 20, 2016.

SANTOS, I.M. et al. Predação de sementes por insetos em três espécies simpátricas de Copaifera L. (Fabaceae). Biotemas, v.28, n.2, p.87-95, 2015. Available from: <https:// periodicos.ufsc.br/index.php/biotemas/article/view/21757925.2015v28n2p87/29245>. Accessed: July 26, 2016. doi: $10.5007 / 2175-7925.2015 \mathrm{v} 28 \mathrm{n} 2 \mathrm{p} 87$.

SARI, L.T. et al. Insects Associated with Seeds of Lonchocarpus muehlbergianus Hassl. (Fabaceae) in Tres Barras, Parana, Brazil. Neotropical Entomology, v.31, n.3, p.483-486, 2002. Available from: <http://www.scielo.br/scielo.php?pid=S1519566X2002000300023\&script $=$ sci_abstract\&tlng=pt $>$. Accessed: July 26, 2016. doi: 10.1590/S1519-566X2002000300023.

SILVEIRA, V.R. et al. Larvas de insetos associadas a Clusia hilariana Schltdl. (Clusiaceae) na Restinga de Jurubatiba, RJ, Brasil. Revista Brasileira de Entomologia, v.52, n.1, p.57-61, 2008. Avaliable from: <http://www.scielo.br/pdf/rbent/v52n1/10. pdf $>$. Accessed: May, 18, 2017.

TRAVESET, A. et al. The ecology of seed dispersal. In: GALLAGHER, R.S. Seeds: the ecology of regeneration in plant communities. 3.ed. United Kingdom: CABI, 2014. Chapt.3, p.6293. Available from: $<$ http://cfe.uc.pt/files/traveset_et_al_2014_cabi the ecology_of seed_dispersal.pdf $>$. Accessed: Feb. 02, $201 \overline{7}$.

VIANNA, M.C. O gênero Vochysia Aublet (Vochysiaceae) no Estado do Rio de Janeiro. Rodriguésia, v.32, n.55, p.237326, 1980. Available from: <http://rodriguesia.jbrj.gov.br/ FASCICULOS/Rodrig32-n55-1980/237\%20-\%20vochysiaceae. pdf $>$. Accessed: July 26, 2016.

ZHANG J. et al. Insect predation of seeds and plant population dynamics. Maine: Agricultural and Forest Experiment Station. 1997. 32p. (Technical Bulletin 163). Available from: <http://digitalcommons.library.umaine.edu/ cgi/viewcontent.cgi? article $=1039 \&$ context $=$ aes_techbulletin $>$. Accessed: July 26, 2016 